\title{
STRATEGY FOR MICRO, SMALL AND MEDIUM BUSINESS DEVELOPMENT STRATEGIES ECONOMY IN COASTAL COMMUNITIES (Case Study on Shrimp Sambal Business in Lamongan District)
}

\author{
Wahyu Endriyanto, Sutikno Wahyu Hidayat, Fa'iq Mumtaz M \\ ${ }^{1}$ Indonesian Naval Technology College, \\ Bumimoro-Morokrembangan, Surabaya 60187, Indonesia
}

\begin{abstract}
This study aims to determine the development strategy of Micro, Small and Medium Enterprises (UMKM) in strengthening the populist economy of coastal communities in shrimp sauce business in Lamongan Regency. The approach used in this study is a qualitative approach. The subject of the research is the shrimp chili business owner in Lamongan Regency. The data analysis techniques used are qualitative analysis techniques and SWOT analysis. Where qualitative analysis uses triangulation data collection techniques while SWOT analysis is used to identify various factors systematically and formulate a company's strategy. The results of this study indicate that the strategy of developing small businesses in strengthening the people's economy in the shrimp chilli business in Lamongan Regency that can be used is the development of markets and products, as well as intensive market penetration by increasing promotion, quality, and innovation of marine products of Lamongan Regency.
\end{abstract}

Keywords: Development strategy, strengthening people's economy, UMKM.

\section{INTRODUCTION}

One of the strategies carried out by the government in sustaining economic development is to empower and grow Micro, Small and Medium Enterprises (UMKM) as the basis for popular economic development. History has shown that UMKM in Indonesia still exist and develop despite the economic crisis.

But on the other hand, UMKM also face many problems, namely the limited working capital, the low quality of Human Resources, and the lack of mastery of science and technology. Other problems faced by UMKM are the connection with the lack of clarity about business prospects and planning, and the lack of vision and mission. This happens because in general, UMKM are income gathering, which is to increase revenue. These characteristics can be seen in micro, small and medium businesses today, generally are family-owned businesses, the use of technology is still relatively simple, lacks access to capital (bankable), and there is no separation of business capital with personal needs.

This condition also occurs in UMKM in the coastal regions of East Java, especially in the Lamongan Regency. In Lamongan Regency there are 130,006 Micro and Small and Medium Enterprises (UMKM) that have absorbed 327,422 workers. This data is data in 2016 based on the Economic Census conducted by the Central Statistics Agency (BPS). Of the existing UMKM, the majority are dominated by businesses or industries utilizing sea products in Lamongan Regency, one of which is shrimp sauce. Lamongan shrimp sauce business is one of the special souvenirs of Lamongan Regency which is a special attraction for local tourists from various regions who are visiting
Lamongan City and other areas. However, the sale of the Lamongan shrimp sauce business has now begun to decline, especially in the Lamongan district. At present the shrimp chilli business tends to be empty of visitors. This is due to customers who generally are people who travel across the city both to and back from Lamongan city, preferring to buy other types of food products to be used as souvenirs. One factor that causes this is the lack of available parking. In addition, the monotonous taste variant is also an inhibiting factor in the development of shrimp chili business in Lamongan Regency.

Efforts to increase economic development on the coast, especially spurred in increasing people's income, cooperatives are an alternative to empower the community's economy. For cooperatives to grow and develop, supporting factors must also be developed. The results of observations in the field found several factors supporting regional economic development through cooperative development, including: 1) community potential; 2) businessman; 3) credit institutions; 4) related institutions; and 5) cooperatives as business entities (Almasdi Syahza, 2010).

Seeing this, business actors should have a strategy in overcoming the problem. This is because the development of the shrimp chili business industry in Lamongan Regency has a very good prospect in supporting the economic growth of the Lamongan Regency.

The shrimp chili business is important and quite interesting to be investigated because of the growing development of the shrimp chili business industry in the area, it is also needed a fairly large market to be able to market the results of the shrimp chili business. Stable finance is also needed to 
maintain the stability of the shrimp chili business. After gathering a variety of strategic issues that need to be considered in the development of UMKM, especially in the development of Lamongan shrimp sauce business products, the needs of markets and financial access were identified. In order to develop UMKM products, in this case the Lamongan shrimp chili business product, it is necessary to examine what strategies can be done to develop the shrimp chili business in the Lamongan Regency.

Based on the description above, the problem formulation in this research is what strategies can be formulated in the development of shrimp chilli business in strengthening people's economy? While the purpose of this research is to formulate a strategy for developing shrimp sauce business in strengthening people's economy.

In the writing of this journal is also used a lot of literature as a reference to support the research conducted, such as including the following: Analisis Strategi Pengembangan Usaha Kopi Luwak (Studi Kasus UMKM Careuh Coffee Rancabali-Ciwidey, Bandung) (Supriatna, 2014). Strategi Pengembangan Usaha Pada "Rihana Bakery" Sidoarjo" (Primawardana, 2015). The results of his research show that Yulia bakery has several interrelated strengths, weaknesses, opportunities and threats. Business development strategies that are consistent with the results of the SWOT analysis. The strategies that can be used by Rihana Bakery are market penetration, market development, and product development. Business development includes several aspects, such as marketing, finance, production and human resources.

This research is organized as follows, chapter 1 introduction, chapter 2 shows material and methodology, chapter 3 shows the results of data and discussion, chapter 4 conclusion.

\section{MATERIALS AND METHODS 2.1. Strategy Definition}

Strategy is a tool to achieve long-term goals. In addition, the strategy is also interpreted as a potential action that requires top-level management decisions and company resources in large numbers (David, 2006).

UMKM Strategy and Development Strategy is the way a company's business leader realizes his philosophy. This understanding emphasizes strategy should be related to large decisions faced by individuals or organizations in doing business that is a decision that determines the failure and success of individuals or organizations (Kuncoro, 2005).

In general, the strategy is a comprehensive approach related to the implementation of ideas / ideas, planning, and implementation of an activity within a certain period. A good strategy requires more work team coordination, has a theme, identifies supporting factors that are in accordance with the principles of rational implementation of ideas, is efficient in funding, and has tactics to achieve goals effectively. Strategy is also a broad set of organizational plans for implementing decisions taken to achieve organizational goals. The strategy into three groups that can be considered to be applied in a company, namely: (1) corporate strategy (corporate strategy), (2) business strategy or competitive strategy, and (3) functional strategy (Sudaryanto, 2011).

\subsection{Definition of People's Economy}

The people's economy can be understood from two approaches, namely: first, the approach of economic activities of small-scale economic actors (people's economy). Empowerment of the people's economy in this approach is intended as an empowerment of small-scale economic actors. Second, the economic system approach, namely economic democracy or a democratic development system (participatory development). Empowerment of the people's economy in this approach is intended to apply the principles of democracy in development. This means that the people's economy is an economic system that includes the entire community in the development process as a driver of development. Thus the second approach is also referred to as a populist economy or a populist economic system (A. Z. Yasin, 2002).

Some things that must be considered in the economic system that leads to populist economy are: (1) the characteristics of the region and the background of the expertise of the majority of the local community, (2) a people-based economy that is economic activities in accordance with the expertise of the majority of the local community, (3) regional characteristics namely increasing the value (value) of regional potential, (4) the role of local government that is encouraging the growth of the people's economy through the improvement of facilities and infrastructure so that the people's economy grows and develops rapidly, (5) local / UMKM potential that is encouraging the growth of potential-based industries local / UMKM by empowering the formation of cooperatives or productive units (Zulkarnain., 2003).

This research was conducted in Lamongan Regency on shrimp sauce business. The site selection technique was carried out deliberately by first observing to find out what agro-economic potentials could be developed in Lamongan District, then one of the outstanding potentials was chosen, namely the shrimp chili business, the research was conducted in July 2016 until August 2016. The informants of this study were the shrimp chili business owners in Lamongan Regency. Data sources from this study consisted of interviews with business owners of shrimp sauce and data obtained from internet sites, journals and other articles related to this research. Data collection techniques used in this study are observation, interviews, and documentation. Data analysis techniques used in 
this study are qualitative analysis and SWOT analysis.

\subsection{Definition of coastal communities}

Coastal communities are meant to mean people who live in coastal areas and their sources of economic life depend directly on the use of marine and coastal resources through fishing and cultivation activities. Poverty as an indicator of backwardness of coastal communities is caused by three main things, namely structural, superstructural, and cultural poverty (Nikijuluw, 2003).

Structural poverty is the social-economic structure of society, the availability of development incentives or disincentives, the availability of development facilities, the availability of technology, and the availability of development resources, especially natural resources.

a. Superstructural poverty is poverty caused by macro policy variables that do not or do not favor the development of fishing communities.

b. Cultural poverty is poverty that is caused by variables that are inherent, inherent, and become a certain lifestyle that makes the individual concerned difficult to get out of poverty because these factors are not realized or unknown by the individual concerned.

\subsection{Research Methodology.}

To solve problems in the observed research, steps are needed and determined to describe the approach and model of the problem. The steps taken are:

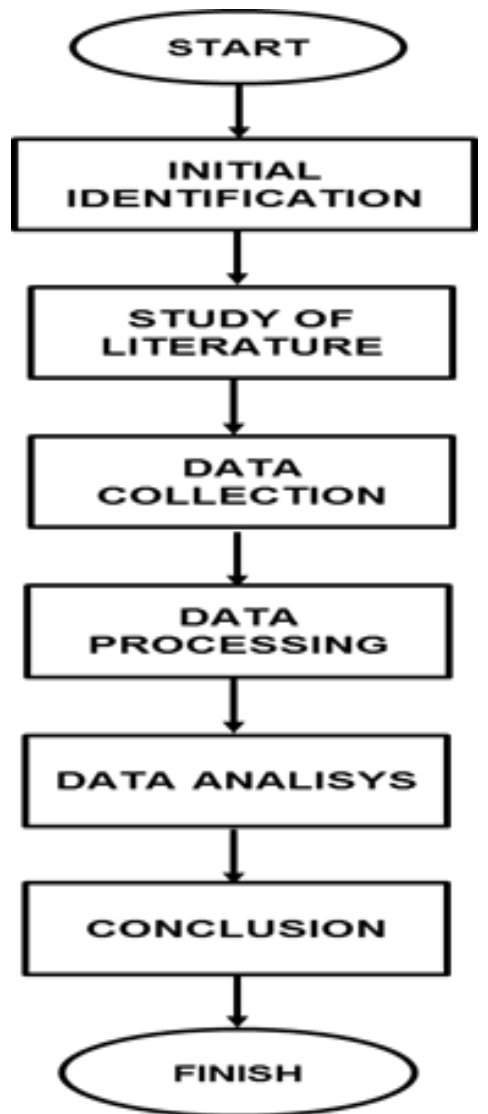

Fig. 1. Research Methodology Flowchart.
Target: the purpose of this study is to produce a strategy in the development of shrimp chili business in the empowerment of the populist economy of coastal communities.

Steps: the steps of this research are step 1 Determine the criteria step 2 determine the suitability of each alternative rank on each criterion step 3 enter interview data in the table, quantitative test analysis Good step 2, step 3 on normalizing the behavior adjusted for attributes attributes or cost benefits) so that the normalized matrix is obtained, step 4 the final result is obtained from the ranking process that is the sum of the normalized multiplication matrix, step 4 provides suggestions for improvement and testing.

\section{RESULT AND DISCUSSION}

Factors That Influence UMKM Development Strategies in Strengthening Community Economy

\subsection{Internal Factors (Strengths and Weaknesses)}

There are several internal factors that have been identified as the strength of the UMKM development strategy, especially the shrimp sauce business in strengthening the populist economy of coastal communities, namely: 1) Convenience of strategic places and locations, 2) Relatively affordable prices, 3) Raw materials that are always available, 4) Taste variations of Lamongan shrimp sauce, 5) Various kinds of companion products offered, and 6) Good communication and familiarity of employees. After being identified, there are also some internal factors that become the weakness of UMKM development strategies, especially the natural shrimp sauce business to strengthen the populist economy of coastal communities, namely: (1) Limited capital, (2) Business management systems that are still weak, (3) Quality and quantity Limited human resources, (4) Marketing (promotion) that has not been intensive, and (5) Supporting production equipment is still limited.

\subsection{External Factors (Opportunities and Threats)}

External factors that provide opportunities for developing UMKM strategies, especially shrimp sauce business in Lamongan Regency, are: (1) Support from the government, (2) Technology and information development, (3) Business expansion (expansion), and (4) Good relations and customer loyalty. Whereas the threats to the UMKM development strategy especially the shrimp sauce business in Lamongan Regency are: (1) Unstable raw material prices, (2) The emergence of new competitors with the same product, (3) The emergence of Competitors offering different products, and (4) Location between businesses that are close together. Internal Factor Evaluation (IFE) and External Factor Evaluation (EFE) matrices. 
Table 1. Evaluation of Internal Factors of Shrimp Sauce in Lamongan District

\begin{tabular}{|c|l|c|c|c|}
\hline No & \multicolumn{1}{|c|}{ Internal Factors } & Weight (a) & Rating (b) & Value (a)x(b) \\
\hline 1 & Strength (+) & & & \\
\hline & $\begin{array}{l}\text { 1. Convenient Location and } \\
\text { Strategic Location }\end{array}$ & 0,15 & 4 & 0,6 \\
\hline & $\begin{array}{l}\text { 2. Prices are relatively } \\
\text { affordable }\end{array}$ & 0,05 & 2 & 0,1 \\
\hline & $\begin{array}{l}\text { 3. Variations in taste } \\
\text { Lamongan shrimp sauce }\end{array}$ & 0,15 & 3 & 0,45 \\
\hline & $\begin{array}{l}\text { 4. Various kinds of companion } \\
\text { products offered }\end{array}$ & 0,05 & 3 & 0,15 \\
\hline & $\begin{array}{l}5 . \text { Good communication and } \\
\text { familiarity of employees }\end{array}$ & 0,1 & 4 & 0,4 \\
\hline 2 & Weakness (-) & 0,1 & 3 & 0,3 \\
\hline & 1. Limited capital & 3 & 0,15 \\
\hline $\begin{array}{l}\text { 2. The business management } \\
\text { system is still weak }\end{array}$ & 0,05 & 4 & 0,6 \\
\hline & $\begin{array}{l}\text { 3. Limited quality and quantity } \\
\text { of human resources }\end{array}$ & 0,15 & 4 & 0,6 \\
\hline & $\begin{array}{l}\text { 4. Marketing (promotion) that } \\
\text { has not been intensive }\end{array}$ & 0,15 & 2 & 0,1 \\
\hline & $\begin{array}{l}\text { 5. Supporting production tools } \\
\text { are still limited }\end{array}$ & 0,05 & & 3,45 \\
\hline & Amount & 1 & & \\
\hline
\end{tabular}

Table 2. Evaluation of External Factors of Shrimp Sauce in Lamongan District

\begin{tabular}{|c|l|c|c|c|}
\hline No. & \multicolumn{1}{|c|}{ Eksternal Factors } & Weight (a) & Rating (b) & Value (a)x(b) \\
\hline 1 & Opportunities (+) & & & \\
\hline & $\begin{array}{l}\text { 1. Support from the } \\
\text { government }\end{array}$ & 0,2 & 4 & 0,8 \\
\hline & $\begin{array}{l}\text { 2. Development of technology } \\
\text { and information }\end{array}$ & 0,15 & 4 & 0,6 \\
\hline & $\begin{array}{l}\text { 3. Business expansion } \\
\text { (expansion) }\end{array}$ & 0,05 & 3 & 0,15 \\
\hline & $\begin{array}{l}\text { 4. Good relations and } \\
\text { customer loyalty }\end{array}$ & 0,2 & 4 & 0,8 \\
\hline 2 & Threat (-) & 0,15 & 4 & 0,6 \\
\hline & $\begin{array}{l}\text { 1. Unstable raw material prices } \\
\text { 2. The emergence of new } \\
\text { competitors with the same } \\
\text { product }\end{array}$ & 0,1 & 3 & 0,3 \\
\hline $\begin{array}{l}\text { 3. The emergence of } \\
\text { Competitors who offer }\end{array}$ & 0,05 & 3 & 0,15 \\
\hline & $\begin{array}{l}\text { 4. Location between stores that } \\
\text { are close together }\end{array}$ & 0,1 & 2 & 0,2 \\
\hline & Amount & 1 & & 3,6 \\
\hline
\end{tabular}

Table 2 shows that the highest scores for opportunity aspects are support from the government (0.8) and good relations and customer loyalty (0.8), technological development (0.6), and business expansion (0.15). So it can be said that the support factor from the government and good relations and customer loyalty can be used as the main opportunity in developing the business.

Meanwhile, the factors that pose a threat with the highest value are unstable raw material prices (0.6), the emergence of new competitors with the same product (0.3), location of stores that are close together (0.2), and the emergence of competitors with different products. The factor with the highest value indicates that the factor is a serious threat to the sustainability of the business going forward.

\subsection{Analisis matriks Internal dan Eksternal (I- E)}

The I-E (Internal-External) matrix is produced by combining information obtained from the EFE and IFE tables to obtain information about the company's position to facilitate the provision of alternative strategies. EFE matrix value of 3.6 indicates that shrimp chili business has a high ability to take advantage of opportunities and avoid existing threats. While the IFE matrix value of 3.45 shows that the shrimp chili business has a high internal factor in utilizing the strengths it has to overcome the existing internal weaknesses.

Based on the EFE and IFE matrix values, obtained the competitive position of shrimp sauce business in quadrant $I$. In that position, the best strategy to do is the strategy of shrimp sauce growth, market and product development, as well as intensive market penetration by increasing promotion, quality, and product innovation Lamongan shrimp sauce business.

\begin{tabular}{|c|c|c|c|c|c|}
\hline & & & \multicolumn{3}{|c|}{ SCORE TOTAL IFE } \\
\hline & \multirow{2}{*}{\multicolumn{2}{|c|}{4,0}} & 3,0 & 2,0 & 1,0 \\
\hline & & & STRONG & MEDIUM & WEAK \\
\hline \multirow{3}{*}{ 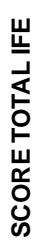 } & STRONG & 3,0 & I & II & IIII \\
\hline & MEDIUM & 2,0 & IV & V & VI \\
\hline & WEAK & 1,0 & VII & VIII & IX \\
\hline
\end{tabular}

Figure 2. Matrix I-E Lamongan shrimp chili business

Table 3. SWOT analysis matrix

\begin{tabular}{|c|c|c|}
\hline \multirow[b]{2}{*}{ EFAS } & \multicolumn{2}{|c|}{ Internal factors } \\
\hline & \begin{tabular}{|l|} 
Strengths (S): 1. Comfort of place \\
and strategic location. 2. Prices \\
are relatively affordable. 3. Raw \\
materials that are always available. \\
4. Variations in chili sauce. 5. \\
Various kinds of companion \\
products offered. 6 . Good \\
communication and familiarity with \\
employees.
\end{tabular} & $\begin{array}{l}\text { Weakness (W): 1. Limited capital. } 2 \text {. } \\
\text { Limited quality and quantity. } 3 \text {. The } \\
\text { business management system is still } \\
\text { weak. 4. Marketing (promotion) that } \\
\text { has not been intensive. } 5 \text {. Supporting } \\
\text { production tools are still limited. }\end{array}$ \\
\hline \multicolumn{3}{|l|}{ Eksternal Factors } \\
\hline Opportuny (0) & So Strategy & WO Strategy \\
\hline $\begin{array}{l}\text { 1. Support from the } \\
\text { government } 2 \text {. } \\
\text { Development of } \\
\text { technology and } \\
\text { information } 3 \text {. Expansion } \\
\text { (expansion) of the } \\
\text { business } 4 \text {. Good } \\
\text { relations and customer } \\
\text { loyalty }\end{array}$ & $\begin{array}{l}\text { 1. Doing innovation and product } \\
\text { variations in attracting and growing } \\
\text { customer loyalty and supporting } \\
\text { business expansion in the future. } \\
\text { customers ( } \mathrm{S} 4, \mathrm{~S} 5, \mathrm{~W} 3 \text {, and W4) } \\
\text { 2. Increase business potential by } \\
\text { utilizing strategic locations and the } \\
\text { development of access to } \\
\text { technology and information. (W1 } \\
\text { and O2) 3. With the government's } \\
\text { support the production and sales } \\
\text { processes can be maximized, and } \\
\text { the stability of the selling price can } \\
\text { be maintained. (S2, S3, S6, and } \\
\text { W1) }\end{array}$ & $\begin{array}{l}\text { 1. Capital limitations and production } \\
\text { support tools can be overcome by } \\
\text { government funding (W1 and 01) } 2 \text {. } \\
\text { Improving and tightening the } \\
\text { management system and employee } \\
\text { recruitment so as not to hamper } \\
\text { business progress. (W2, W3, and O3) } \\
\text { 3. Maximize the use of promotional } \\
\text { media such as print and electronic } \\
\text { media to reach more consumers. } \\
\text { (W4, O2, and O4) Efforts to improve } \\
\text { business management systems, } \\
\text { human resources quality, intensive } \\
\text { marketing patterns, and production } \\
\text { technology are needed in overcoming } \\
\text { existing problems and existing } \\
\text { business competition. (W1-W5 and } \\
\text { 04) }\end{array}$ \\
\hline Threats $(\mathrm{T})$ & \begin{tabular}{|c|} 
ST Strategy \\
\end{tabular} & WT Strategy \\
\hline $\begin{array}{l}\text { 1. Unstable raw material } \\
\text { prices } 2 \text {. Emergence of } \\
\text { new competitors with the } \\
\text { same product } 3 \text {. } \\
\text { Emergence of } \\
\text { Competitors offering } \\
\text { different products } 4 \text {. } \\
\text { Locations between stores } \\
\text { that are close together }\end{array}$ & $\begin{array}{l}\text { 1. Maintain and enhance customer } \\
\text { satisfaction through consistency in } \\
\text { the quality, variety and innovation of } \\
\text { the products offered. (S3, S4, S5, } \\
\text { T2, and T3). 2. Utilizing strategic } \\
\text { locations and providing special } \\
\text { promos for customers to attract } \\
\text { customers (S1, S2, S6, T1, and } \\
\text { T2) }\end{array}$ & $\begin{array}{l}\text { 1. Efforts to improve business } \\
\text { management systems, human } \\
\text { resources quality, intensive marketing } \\
\text { patterns, and production technology } \\
\text { are needed in overcoming existing } \\
\text { problems and existing business } \\
\text { competition. (W1-W5 and T1-T4) }\end{array}$ \\
\hline
\end{tabular}


Based on the results of the SWOT analysis and the value of the EFE (External Factor Evaluation) and IFE (Internal Factor Evaluation) matrix, it can be seen the position of the development of shrimp sauce business in Lamongan Regency in quadrant I. In that position, the best strategy is a growth strategy. Shrimp sauce business in Lamongan Regency develops markets and products, as well as intensive market penetration by increasing promotion, quality, and product innovation Lamongan shrimp sauce business. Overall, from the analysis of these factors, several business development strategies can be formulated as follows.

a. Strategic location

Location is the location or place where a business is carried out. According to Kotler (2008: 51) "One of the keys to success is location, location begins by choosing the community". This decision is very dependent on the potential for economic growth and stability, competition, political climate, and so on. The location greatly affects the number of shrimp chilli business sales in Lamongan Regency. The closer to the axle, the greater the opportunity for a business to develop.

b. Maximizing Capital Assistance from the Government

Apart from private capital, capital is also obtained from the government in the form of People's Business Credit (KUR). The government is also responsible for the sustainability of micro small and medium enterprises. This is in line with several opinions of experts, as stated by Hafsah (2004: 4344) that the development of SMEs is essentially a shared responsibility between the government and the community.

c. Increase sales capacity.

The strength factor in the form of the availability of stable raw materials can be used to take advantage of existing opportunities, namely improving the condition of the Indonesian economy followed by increased purchasing power, as well as technological advances and assistance from the government, this opportunity can be taken by the Lamongan shrimp sauce business in Lamongan Regency, one of them is by increasing sales capacity. Maximize the number of repeat customers. By utilizing internal strengths in the form of ability to meet demand according to customer needs, able to maintain continuity to meet existing demand, already have regular customers but still few in number, and establishing good relationships with all customers can be a capital to take advantage of opportunities that exist namely relationships both with buyers / customers, by utilizing the existing trust can be increased to become regular customers of the Lamongan shrimp chili business.

d. Doing innovation and product variations The number of competitors that have sprung up encourages the need for innovation and product variations. This is necessary to maximize sales and attract the attention of customers. These innovations include making variations in the taste of the Lamongan shrimp sauce business, and adding to the variety of products offered at the store.

e. Utilization of technology in conducting intensive promotions By promoting more aggressively, the shrimp chilli business in Lamongan Regency can overcome the weaknesses of less strategic places because the location is far from the main road, as well as the weaknesses of aggressive promotion. So the promotion will maximize and utilize the strategic location potential. Not just being a spectator among other entrepreneurs, but can be a player who is able to take the opportunities that exist.

f. Implementation of business management systems, especially in terms of financial and administrative records Business management is an important element in running and maintaining business continuity. Some shrimp chili business owners have not done a good business management system, especially regarding the existing financial or administrative recording system which is a major weakness that must be addressed immediately. Pagaya (2013) states that by making good records it will be known in writing whether the costs incurred by SMEs are efficient, and it can also be known what expense points are inefficient so that the margins of shrimp sauce can be increased.

g. Improving the quality of human resources in order to maximize production capacity. Maintaining good relations and loyalty with all employees, as well as high motivation needs to be maximized again by making efforts to improve employee skills through education and training. Wahyuningtias (2011) argues that with the improvement in the quality of employees it is also expected to be able to synergize with increasing production capacity.

\section{CONCLUSION}

Factors that become the strength of the shrimp chili business include the convenience of a strategic location and location, relatively affordable prices, variations in the flavor of the shrimp shrimp Lamongan, various kinds of companion products offered, as well as communication and familiarity of employees who are well-established. Meanwhile, the factors that become weakness include limited capital, a business management system that is still weak, limited quality and quantity of human resources, marketing (promotion) that is not yet intensive, and supporting production tools are still limited. The factors that become shrimp sauce business opportunities include support from the government, development of technology and information, business expansion (expansion), as well as good relations and customer loyalty. While the threat factors include unstable raw material prices, the emergence of new competitors with the same product, the emergence of competitors offering different products (substitute products), as well as locations between businesses that are close together. 
The results of identification of internal factors (strengths and weaknesses) and external factors (opportunities and threats) can be formulated several strategies for shrimp chilli business development, including strategic locations, maximizing capital assistance from the Government, increasing sales capacity, maximizing the number of regular customers, innovating and variety of products, use of technology in conducting intensive promotions, implementation of business management systems, especially in terms of financial and administrative records, and improving the quality of human resources in order to maximize production capacity.

\section{REFERENCES}

A. Z. Yasin, F. (2002). Farmers, Small Businesses and Cooperatives with People's Economy Insight. Pekanbaru: Unri Press.

Almasdi Syahza, H. I. (2010). Agribusiness-Based Cooperative Empowerment in Coastal Areas. Sosiohumaniora Vol. 12, No. 3, 207-220.

David, F. R. (2006). Strategy Management; Tenth Edition Concept Tenth edition. Jakarta: Salemba Empat.
Kuncoro, M. (2005). Strategies How to Achieve Competitive Advantage. Jakarta: Erlangga.

Nikijuluw, V. P. (2003). Socio-Economic Aspects of Coastal Communities and Empowerment Strategies in the context of Integrated Management of Coastal Resources Coastal Resources Management Project.

Primawardana, T. I. (2015). Business Development Strategy in "Yulia Bakery" Sidoarjo ".. AGORA. Vol. 3, No. 2, 364-372.

Sudaryanto, R. d. (2011). Strategy for empowering MSMEs in the ASEAN free market struggle. Jember: Jember State University.

Supriatna, M. A. (2014). Analysis of Luwak Coffee Business Development Strategy (Case Study of SME Careuh Coffee Rancabali-Ciwidey, Bandung). Journal of Management and Organization. Vol V, No 2, 227-243.

Zulkarnain. (2003). Building a People's Economy: Perceptions of Empowerment of the People's Economy. . Yogyakarta: Adicita Karya Nusa. 